\title{
Mapping of Socio-Economic Profiles for River Water Education Tourism
}

\author{
Sherlywati Sherlywati* \\ Management Department, Faculty of Economics \\ Universitas Kristen Maranatha \\ Bandung, Indonesia \\ *sherlywati@eco.maranatha.edu
}

\begin{abstract}
This research provides recommendations for action in order to reduce waste pollution, socialize how to maintain cleanliness from an early age especially in taking care with the river, and strengthen the community economy through the development of alternative economies, especially those based on river water education tourism in Saguling Reservoir inlet. The research question is what efforts can be done to improve water quality and reduce waste pollution that occurs in the Citarum River, especially in the Saguling Reservoir inlet? This research was conducted in Jelegong Village which is one of the villages in the Saguling Reservoir Inlet, and has been running for three months in 2017. As the research sample, Jelegong Village will be presented in this study with the livelihood of the population in the industrial field. The research method was used is Participatory Action Research (PAR), which is a research process that places respondents under study as research partners, both in the process of collecting, compiling, analyzing data, and in the process of drawing conclusion and formulating action of recommendations. This study involved 150 respondents from 50 families in Jelegong. The results from this study, namely, socialeconomic profile of the Jelegong community; which is used to recommend the community to reduce the waste of pollutions in the Saguling Reservoir inlet, specifically in Jelegong region. The formulation of recommendations is built on the concept of propoor tourism on the basis of community development and education on the importance of protecting the river and water. The results of this study offered three strategic arrangements, as follows, first, recommendations on strengthening economic behaviour and controlling pollutant behaviour; second, recommendations for piloting community-based economic development in Jelegong Village; third, recommendations on the establishment of water-based tourism in order to improve the quality of river water; and in addition, recommendation on conducting further surveys to deepen this research.
\end{abstract}

Keywords-socioeconomics mapping, pro-poor tourism supply chain management, water-based tourism, participatory action research

\section{INTRODUCTION}

Citarum river is the longest river in West Java, Indonesia, with the length $270 \mathrm{~km}$. Citarum river has three reservoirs, i.e. Cirata, Jatiluhur, and Saguling. These reservoirs function as power plant, field irrigation, and become a source of drinking water. The Saguling Reservoir began construction in August 1981, was operated in 1985, and was only inaugurated in 1986 by the 2 nd President of Republic Indonesia, Suharto. The construction of this reservoir spend fund USD 662,968,000 including land acquisition costs. There were 49 villages, most of which include agricultural land, which have been submerged under water and 12,489 families have been forced to move, including those who have been moved through the migration program outside of Java. The construction of the reservoir is actually a manifestation of the great idea of a Dutch engineer, Prof. Ir. W. J. van Blommestein, who was obsessed with integrating all irrigation channels in West Java from CiujungBanten, to Sungai Rambut on the border of West Java with Pekalongan-Central Java [1].

The main purpose of Saguling Reservoir construction is as a source of power generation. However, as time passes, Saguling also serves as a source of economic income, such as the place of aquaculture, agri-aquaculture, tourism, and domestic needs such as bath-wash-basin. This is suspected to be the cause of the low water quality and high pollution levels in this reservoir, even worse than the two reservoirs in the Citarum River.

In addition to the issue of water quality and high level of pollution, it is also important and interesting to be examined is, whether the development of the Saguling Reservoir socially and economically became a blessing for people who live in the surrounding area. Preliminary indications suggest that some people who diverted ownership of their land for Saguling project, at present the socio-economic situation was much worse than their previous social economy. This is demonstrated by the number of people who decided to switch professions to become scavengers around the Saguling reservoir, which was once a member of a wealthy peasant family that had its land in use to build Saguling reservoir. This raises the question of whether the construction of Saguling reservoir is a project that is proven to provide lighting to the people of Java and Bali, but is not able to give decent life for those who contribute land to Saguling project.

The results of observations and interviews with the residents around Saguling reservoir, were identified by two groups of respondents with two distinct perceptions of the Saguling reservoir. The first group are those who look at Saguling reservoir as a source of income and are a blessing from which they earn a fortune. The second group are those whose livelihood are not related to the existence of Saguling reservoir. From the initial information, whether is it necessary to explore whether the two groups of people who have different perceptions, also have different attitudes and behaviors in relation to increasing pollution and declining water quality in the Saguling reservoir. 
This research provides recommendations for action in order to reduce waste pollution, improve water quality, and strengthen the community through the development of alternative economies, especially those based on water-tourism through the concept of pro-poor tourism in Saguling reservoir inlet. The research question is what efforts can be done to improve water quality and reduce waste pollution that occurs in the Citarum River, especially in the Saguling Reservoir inlet? And there are three recommendations as the results from this study, first, recommendations on strengthening economic behavior and controlling pollutant, second, recommendations for piloting community based economic development in Jelegong Village, and third, recommendations on the establishment of water-based tourism in order to improve the quality of river water.

\section{CONCEPT}

\section{A. Social Economic Mapping}

In this study, socio-economic mapping is defined as a systematic depiction process and involves the collection of data and information about the community including profiles and social problems in the community. Social economic mapping can also be called as social economics profiling [2]. Social economic mapping can be seen as one of the approaches in community development, defined as the process of assisting ordinary people to improve their own communities by undertaking collective actions [3].

While it is difficult to describe the social economy by focusing on what social economy organizations share, some distinctive features can be identified on the basis of what sets them apart. As a comparation, the social economy in Europe is made up of private socio-economic initiatives that, regardless of their specific legal status, first, produce goods and services for both market and non-market purposes; second, are based on values of sustainability, solidarity, trust, reciprocity, local development, social cohesion and inclusion; third, aim at reinforcement of social cohesion, awareness and citizenship, through internal and external collaboration and collective efforts [4]. These approach is used in finding and creating pro poor tourism models in this study.

\section{B. Pro Poor Tourism}

Pro-Poor Tourism (PPT) is a concept of tourism where all the benefits are addressed to the poor, and ensure that tourism growth contributes to the poverty reduction [5]. PPT is not a specific product or sector of tourism, it's an approach with aim to unlock opportunities for the poor, whether for livelihood benefits, or economic gain, and also participating in decision making. Bennet et. all and Ashley et. all, state that the principles in PPT are:

- A PPT strategy needs to be followed by infrastructure improvement.

- The principles of PPT also apply to all segments required for strategic diversity such as mass tourism and wildlife tourism.

- Focus on increased benefit and not just reduce costs.
- Learn to apply other sectors such as small business and good governance in the world of tourism.

- Making tourism as a business realistically.

- Do not expect the same benefits received by each individual poor community.

- Leaning while practicing.

\section{RESEARCh METHODOLOGY}

\section{A. Research Types and Methods}

The research used is Participatory Action Research (PAR) method. PAR is a method of research that is based on the collaboration between researchers and respondents in two ways, direct involvement and direct action of community which is the main actors of the research. PAR is a qualitative research methodology option that requires further understanding and consideration. PAR is conducted in a democratic, dynamic, and participatory manner in which all research activities are carried out with the aim of developing and advancing aspects of the life of a community [6]. An attribute of action research that the problem is defined by the people who believe and feel that the problem is really a problem in the local setting and the solution to the problem is within the same setting without intention of generalizing its results [7].

The results of PAR also provided practical knowledge for the development of community life in various aspects, such as health, economics, psychology, environment, and so on. In its implementation, PAR makes the society studied as working friend not as a research object, so that, the community participated directly in formulating issues, information gathering, data processing, conclusion taking, making recommendations and next action plans [7]. PAR activities consisting of several points starting from the introduction of the problem (defining the issue), planning the action to be taken in connection with the issues arising (planning action), taking an action, analysis and reflecting on actions, and the adjustment of the results of the decision with the real-world setting [8]. PAR's method gave the possibility to researchers and respondents to interpret data and information accurately, and also more appropriate formulation of action recommendations needed to answer the research questions [9].

\section{B. Research Instruments}

At level of implementation in the field, the generic PAR method was concretized with the application of Participatory Rural Appraisal (PRA), which has been used by World Bank. The method PRA as a variant and derived of PAR. PRA is a research method that emphasizes the importance of local knowledge and encourages local people to be able to analyze, assess, and find solutions to the problems that exist in their surroundings. The PRA approach, as well as PAR in general, strongly prioritizes community involvement as a lead actor, and only places researchers as facilitator who help run the research. This means that all phases of collecting data and information, assessment, analysis, evaluation, and decision making are almost completely determined by the community itself. The role of researcher as facilitator only helps to ensure the whole process is running as it should. This can be done by some of the instruments, such as social economic map, transect village, 
seasonal calendar, Venn diagram, livelihood analysis, and focus group discussion [10]. In this study, researcher focused with socio-economic map and focus group discussion.

\section{Research Design}

Three villages were selected from all village located around Saguling inlet area. In this study, in particular, Jelegong Village will be discussed as a village pilot that is still experiencing the effect of waste and water disposal pollution. The respondents of this research are the entire part of Jelegong Village, ranging from the head of the family, village official, village figures, entrepreneur in Jelegong, and the community in the Jelegong Village.

This research has begun since 2014 and the further research was conducted in 2017. For the first time in 2014, three researchers lived in the village for three months. Researchers approached and observed the behavior of handling garbage and river water pollution by the residents. Researchers made socioeconomic mapping for three villages in Saguling reservoir inlet are, and then, in 2017, researchers returned again to deepen and follow up the recommendation from the first research. And in 2017, researchers focused for planning action and implementing the research recommendations in Jelegong Village.

After conducted socio-economic mapping, the researcher conducted an intense focus group discussion with Jelegong's stakeholder. The concept raised in the discussion forum is propoor tourism and public policy that supports the implementation of tourism activities in the village.

\section{RESULTS AND DISCUSSIONS}

\section{A. Jelegong Profile}

Jelegong Village is a village located in the administrative area of Kutawaringin Subdistrict, West Java with an area about 315.20 ha and a population of 16,834 inhabitants. At a glance, Jelegong Village is seen as a region that still relies on the agriculture sector as its flagship livelihood, but if it is traced deeper, the industry sector becomes the main livelihood of Jelegong Village, with large, medium, and small scale. Awareness level of education is good enough, with average is high school level. The majority of the community is moslem with two denominations, namely Sunnah and Wahabi. The inhabitants of this village are still dominated by people of the Sundanese people, and most are the indigenous people of Jelegong Village. Migrants who enter Jelegong Village come from various ethnic backgrounds, such as Batak, Minang, and Javanese.

Topographically, Jelegong Village is a flat valley with many watercourses from Citarum River. Besides the Citarum River, Jelegong have four mountains, Lalakon, Badaraksa, Paseban, and Pacir Mountain. One of the mountains that has begun to look barren is Pacir Mountain, which is taken soil as a material to make sand, raw material, or brick. The mountain is already owned by a company and has begun to be depleted.

Jelegong Village still has a large enough agricultural land but according to the chairman of the Gapoktan (community of farmer) of Jelegong, that the area of farmland in Jelegong has begun to diminish, one example is KIP (Industrial area Park), formerly a farmland, was transformed into a storage warehouse for the industry. The remaining farmland in Jelegong village is generally owned by outside village or factories. Therefore, if we look at a glance it will think that this village is quite prosperous, many land that can be used as a plantation, even forestry, but the problem is the ownership of land has changed, so that it can't plant again.

The settlement of Jelegong Village is scattered at several points and there are already three quite elite housing. The house in Jelegong has been dominated by permanent wall building and been electrified. In the morning and afternoon, the village is quite deserted because everyone works as laborer. Young people are rarely seen because most of them are workers too. The main problem in the settlements of Jelegong is the garbage that is scattered in the roads and yards. Garbage types that are widely encountered is the snack packaging garbage. Garbage stacks are often found on the streets.

\section{B. Socio-economic Mapping}

In this session, socio-economic mapping with five instruments, namely transect village, venn diagram, livelihood analysis, and intensive focus group discussion will be described in narrative with paragraphs and at once is a summary of the results of socio-economic mapping.

Jelegong village is one of the village that located in the Saguling inlet area. Because of its close proximity to Saguling reservoir, Jelegong is one of the villages that are contaminated with garbage and water pollution. Many residents have given their land for the development of Saguling, but now their social economics life is much worse compared to the condition before the construction of Saguling. The livelihood of rice and corn farmers began to shift into labor/employee, scavengers, garbage broker, and small entrepreneur. The agricultural land is reduced and transformed into a region of industry.

Facilities and infrastructures that facilitate economic activities have been developed, such as gas stations, LPG fuels, bank, minimart, public transportation, and online transportation. All of these economics facilities cause the Jelegong's economic spin rapidly. The significant thing about the economy in Jelegong is the existing of gas station. Growth in private vehicle ownership is high enough to have an impact on the productivity of citizens' economic activities. Another important economic public facility is the BRI Teras Bank which provides credit for those who want to start a business or just borrow money for their daily needs. And another part that support Jelegong's economy is traditional market, which is called Pasar Raya Patrol.

Some Jelegong's facilities still need to be improved such as an irrigating rice fields, landfills, damaged, and potholes on roads, and bad street lighting. The irrigation of rice fields in Jelegong uses an irrigation farming system. The irrigation channel in Jelegong has been built since the colonial era. The water from irrigation canal is quite clean, but unfortunately there are still people who throw garbage into canal so that several times this canal has to be cleaned by farmers. Another problem is the irrigation path to the Jelegong's agricultural land is quite far from the center of irrigation waters.

Other facilities that are still not good are the absence of landfills (TPS) and the patrol posts that are no longer in use and are not maintained. Landfills are vital in an area. According to village official, Jelegong is currently working on 
the construction of a polling station and is still in talks with the sanitation department and is looking land that can be used as a polling station. And many roads in Jelegong looks destroyed and have holes. Many streets and alleys are still left untouched by government programs. Lighting is also still lacking, even if it is far from the main road, the road and alley conditions are very dark so that it triggers the emergence of criminal acts in Jelegong Village.

Educational facilities have started to increase, the building has been renovated, equipped with a library. Education starts from PAUD (early childhood education programs) and Kindergarten level up to elementary school. There are 5 elementary schools, unfortunately there is no junior high school and high school level. There is only one informal education in the form of sewing courses which are the activities of PKK group. The distance between primary school are too close, so it's difficult to reach by residents who live in certain areas.

Health facilities and infrastructure are still quite minimal. Buildings and medical devices are still lacking, health facilities in the form of puskesmas pembantu (supporting health centers). Diseases that are often afflicted by the public are Acute Respiratory Infections (ISPA) and skin diseases, which are the effects of river water pollution and waste pollution.

A fairly active institutional community is religious institutions. Social institutions consist of PKK (family welfare empowerment), Youth Organization, and Gapoktan (farmer community). PKK are quite active in holding morning gymnastics, posyandu activities, and will open sewing training courses. Gapoktan (community of farmer) is active in conducting seed and plants knowledge, and coordinating on irrigation issues. While the youth group Karang Taruna was not active enough because of the busy work at the factory.

The main problem in Jelegong is garbage on the street and riverbanks. Although there is quite a lot of garbage in the river, but the main pollution is mostly caused by garbage on the streets. This is due to the unavailability of landfills. The Government and the Office have coordinated to solve the waste problem. Scavengers only take plastic bottles waste and used cloth from the factory because they can only sell these waste. Styrofoam, twigs, leaves, water hyacinth isn't taken by scavengers because it cannot be sold and there is no company that can recycle Styrofoam, twigs, leaves, and water hyacinth. Scavengers sell plastic bottle for 1500-2000 rupiah per kilo.

Besides physical waste, river pollution is carried out by factories such as washing factories, garments, concrete blocks, glass, plastic. The company does not yet have a factory waste treatment, and most of the factory's position is near the river bank. The Citarum River in Jelegong is known as the Old Citarum River and the New Citarum River.

When "the old Citarum river" or before Saguling built, people relied on agriculture, plantations, and also fisheries. There is good action of socio-economic between communities and river. The river as a social public space and there are economic activities before Saguling built, such as gardening, rice fields, cattle, bathing, washing, playing children, even for entertainment. And when "the new Citarum river" era, the communities begun to stay away from the river because since the widening of the river and Saguling built, dangerous factory waste polluting their river, causing odors, fish have died.
Jelegong residents switched into laborer and scavengers, they began to move away from the river.

\section{Intensively Focus Group Discussion with Pro Poor Tourism Supply Chain Management Concept}

After conducting socio-economic mapping with Participatory Rural Action, the researcher conducted an intense focus group discussion with the stakeholders listed in the venn diagram, especially the community and village officials. The concept raised in the discussion forum is pro poor tourism and public policy that supports the implementation of tourism activities in the village of Jelegong.

Pro poor tourism is a concept of tourism where all the benefits are addressed to the poor, in this case the residents are disadvantaged because of the pollution of the Citarum river in their village. The results of the discussion are expected to be a real action recommendation in educating the public about river water conservation and reducing pollution and waste pollution, improving water quality, and strengthening the community's economy through local economic development, especially based on river water tourism, are as follow:

- Collaborate with neighbouring village to organize tour package for children with environmental themes and river water awareness and cleanliness from an early age. There is a neighbouring village that has been actively carrying out pro poor tourism regarding the Citarum River concept.

- The government together with Jelegong communities created a waste education centre, starting from how to handle waste, sorting waste, until the form of waste utilization that can be done by themselves in simple ways, such as eco bricks.

- With the unavailability of waste processing centers (both plastic waste and others), Jelegong Village needs to organize a center for processing plastic waste into plastic seeds, Styrofoam waste into glue materials, water hyacinth into raw material for many innovation product. The most appropriate form of waste treatment center is a cooperative or a village-owned enterprise managed by Jelegong Village. It is intended that the selling price of plastic waste per kilo is not too low, invites residents to collect rubbish so that they do not throw garbage on the streets and provide a good example to people outside Jelegong.

- Regarding pollution from factory waste, government policy is needed so that companies provide a waste treatment center before disposal and a strict prohibition so that the waste is not discharged directly into the river. The form of tourism that can be done to these companies is to make a company visit especially so that the company can show good waste management techniques to the public, and also rewarding for great managing plant waste

\section{CONCLUSIONS AND RECOMMENDATIONS}

From the activities of socio-economic mapping and intensive focus group discussions in Jelegong Village, there are some conclusions and recommendations for other research that will empower the communities, such as: 


\section{A. Recommendation on Strengthening Economic Behaviour and Controlling Pollutant Behavior}

As a result of socio-economic mapping, it is seen that there is a lot of garbage that often accumulates on side of the road. The government needs to carry out a campaign so that residents can handle waste better. In addition, the government will build a landfill near the residential areas. Regarding waste management, Jelegong Village has taken the initiative to strengthen economic behavior in terms of handling waste. The government together with Jelegong communities created a waste education center, starting from how to handle waste, sorting waste, until the form of waste utilization that can be done by themselves in simple ways, such as eco bricks. There are some school in Jelegong Village. The Waste Campaign will start from school. Students will be given challenge to waste handling with ecobrick and Bank Sampah. In addition to teach the value of controlling pollutant, students also develop themselves to process waste into economic value. All of housewife in Jelegong Village will be socialized about waste handling and controlling pollutant behaviour too. With Ecobricks and Bank Sampah, Jelegong Village invited to think waste management with economic value that can be obtained from the waste.

\section{B. Recommendations for Piloting Community-based} Economic Development and Establishing the Water based Tourism in order to Improve the Quality of River Water in Jelegong Village

One of the results of the Focus Group Discussion was held a piloting community based on economic development. Jelegong village will collaborate with neighbouring villages to manage the pilot project with the pro poor tourism concept. Pro-poor tourism (PPT) is defined as tourism that generates all benefits for the poor, which may be economic, social or environmental. Jelegong Village needs to adopt the PPT concept in designing a model based on river water education. Piloting community based economic development will be a piloting project in Jelegong Village that will build a tour package for children with the environmental themes and river water awareness from early age. PKK, Gapoktan, and Karang Taruna will be an even organizer for these activities. The purpose of piloting project is to raise concern about the prevention of waste pollutions and how to handle waste management. With the concept of pro poor tourism, event organizer also develops entrepreneurial skill. They have to think how to manage the activities in order to get the profit for their village.

The entrepreneurs who focus on the tourism industry need to help the areas that affected by waste pollution and river water pollution so that these areas can be used as tourism objects. In conducting tourism activities, the poor community is involved as suppliers of raw materials (supply chain) needed. Thus, the benefits of tourism can be felt by the victims, in this case the residents of Jelegong who are victims of waste pollution and river water pollution. Recommendation for piloting community-based economic development made by participatory action research processes. Participatory Action Research Method is very effective method for involving the community in developing village by finding solutions together.

\section{Recommendation on Conducting further Surveys to Deepen this Research}

Participatory Action Research Method is very effective method for involving the community in developing village by finding solutions together. Socio-economic mapping is very useful to know the real condition of an area so that it can find the right problem solving to be applied. The problem of waste and river water pollution is our common problem, not just residents who live near the rivers. Therefore, tourism based river water education is needed. For recommendation on conducting further surveys, researchers suggest to deepen the research with analysing the impact of pro poor tourism concept that was built from participatory action research. All participatory action research conduct based on the results of socio-economic mapping.

\section{REFERENCES}

[1] M.A. Ilyas, "Sedimentasi dan Dampaknya pada DPS Citarum Hulu," Jurnal Teknologi Lingkungan, vol. III, no. 2, pp. 159-164, 2002.

[2] F.E. Netting, P.M. Kettner, S.L. McMurtry and M.L. Thomas, Social Work Macro Practice. New York: Longman, 2012

[3] A. Twelvetrees, Community Work. London: McMilan, 2008

[4] Directorate General for Internal Policies, "Social Economy," European Union, Brussels, 2016.

[5] C. Ashley, D. Roe and H. Goodwin, Pro-Poor Tourism Strategies: Making Tourism Work For The Poor, A review of experience. Nottingham: The Russell Press, 2001.

[6] P. Reason and H. Bradbury, Action Research Participative Inquiry and Practice. California: SAGE Publications, 2008.

[7] M.P.E. Morales, "Participatory Action Research (PAR) cum Action Research (AR) in teacher professional development: A literature review," International Journal of Research in Education and Science (IJRES), vol. II, no. 1, pp. 156-165, 2016.

[8] C. MacDonald, "Understanding Participatory Action Research: A Qualitative Research Methodology Option," Canadian Journal of Action Research, vol. XIII, no. 2, pp. 34-50, 2012.

[9] J.M. Chevalier and D.J. Buckles, AHandbook For Participatory Action Research, Planning and Evaluation, Canada: SAS2 Dialogue, 2011.

[10] World Bank, "Participatory Rural Appraisal," [Online]. Retrieved from http://web.worldbank.org/WBSITE/EXTERNAL/TOPICS/EXTSOCIA LDEV 